\title{
Adaptation of the ADKAR Model to the Management of the Higher Education Student Loan Scheme in Uganda
}

\author{
Hilary Mukwenda Tusiime \\ http://orcid.org/0000-0001-7059-7808 \\ East African School of Higher \\ Education Studies and Development, \\ Makerere University
}

\begin{abstract}
The financing of higher education through student loan schemes is a recent phenomenon in Uganda. It constitutes a major change in the financing of higher education in the country and, naturally, it has not been without controversy. Its processes have posed challenges to both its beneficiaries and implementers. For instance, the loan policy's sustainability is yet to be guaranteed. It is with this understanding that this paper discusses how application of the ADKAR change management model can promote the performance and sustainability of the policy. Designed to help individuals and organisations, the model prescribes a five-step process towards adopting change and leveraging its power to bring about improvement by enhancing ability to confront new situations. In this paper, this process is proposed for ensuring effective disbursement of student loans, determination of interest rates and recovery of the loans from borrowers.
\end{abstract}

Keywords: Funding; Loan scheme; ADKAR.

\section{$1 \quad$ Introduction}

Globally, universities are operating in an ever changing environment; and national government are engaging in a series of initiatives and reforms to address the emerging changes. For instance, grants are being replaced with student loan schemes as a measure to make financing of higher education affordable (Shakeela, 2010). The rising price of attaining higher education has made affordability and accessibility of higher education institutions (HEIs) an increasingly important policy issue in recent years (Woodhall, 2010; 1991). In particular, Uganda has undertaken a lot of reforms

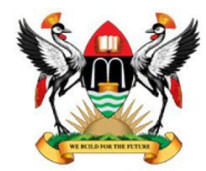

East African School of Higher Education Studies \& Development, Makerere University

\author{
Makerere Journal of Higher Education \\ ISSN: 1816-6822 (Print); 2707-6113 (Online) \\ 11 (1) (2019) $45-57$ \\ DOI: http://dx.doi.org/10.4314/majohe.v11i1.4 \\ (C) The Author(s) 2019 \\ Reprints \& permission: EASHESD \\ http://ajol.info/majohe \\ Conflict of interest: None \\ Funding: None
}

Email: hmukwenda@yahoo.com.

Cite article as: Tusiime, M. H. (2019). Adaptation of the ADKAR Model to the Management of the Higher Education Student Loan Scheme in Uganda. Makerere Journal of Higher Education, 11 (1), 45-57.

http://dx.doi.org/10.4314/majohe.v11i1.4. 
in the area of financing of higher education. Until recently, higher education was mainly offered free of charge in Uganda. However, due to monetary stringency some form of cost-sharing policy was introduced in Uganda around the mid of 1990s to beef up government sponsorship scheme. This intervention has been undermined by surging numbers of candidates qualifying to join tertiary institutions in Uganda; thereby necessitating higher education student loan (Uganda Government, 2012).

Consequently, Higher Education Student Loan was launched in 2014 by Uganda Government to especially benefit less well-off students who miss full government sponsorship. The trends of beneficiaries of Higher Education Student Loan over the years has been as follows:

Table 1. Trends of Beneficiaries of Higher Education Student Loan

\begin{tabular}{lll}
\hline Academic Year & Total Applicants & Number of Loans awarded \\
\hline $2014 / 2015$ & 2,125 & 1,201 \\
$2015 / 2016$ & 4,399 & 1,276 \\
$2016 / 2017$ & 3,764 & 1325 \\
$2017 / 2018$ & 4,218 & 1,448 \\
$2018 / 2019$ & 4,603 & 2,950 \\
\hline
\end{tabular}

Source: Uganda Government (2019).

The objective of the loan scheme is to increase equitable access to higher education in Uganda and to support qualified students who may not afford higher education (Uganda Government, 2014). However, the extent to which government can achieve these laudable and well-articulated objectives depends greatly on the effectiveness of managing the available loan funds in terms on how loans are disbursed and recovery is done.

Having begun in 2014, the first cohort of beneficiaries of Higher education student loan are now out as successful completers of their successful academic programmes. However, the level of readiness to recover from loan beneficiaries is low, the policy is limited in scope of convergence and challenges of how to apply the policy on loan recovery has emerged. Moreover, the policy still grapples with several inhibitions. For instance, the loan caters only for pedagogical (research, functional and tuition fees) and costs for aids and appliances for Persons with Disabilities. The loan was meant to cater for hybrid of science and non-science programmes that are relevant to national development, and students can only apply after being admitted in HEIs. In addition, the loan is extended to only Ugandan students seeking to pursue higher education in an accredited institution of higher learning recognized by National Council for Higher Education (NCHE). The loan is not directly disbursed to the needy student(applicant) but rather to the institution of higher learning where the student is admitted to pursue an accredited programme of study in local public and private chartered universities (Uganda Government, 2014). All these shortcomings may result in high repayment defaults and make realization of the objectives of Higher Education Student Loan Policy next to 
impossible as it is the case elsewhere (Avery \& Turner, 2012; Greene, 1989; Dynarski, 1994; Herr, \& Burt, 2005). This may finally lead to abandonment of the Higher Education Student Loan. Hence, the need to espouse an appropriate model to make smooth the management of Higher Education Student Loan currently offered in Uganda. This why the study sought to explore the relationship between ADKAR model and management of Higher Education Student Loan in Uganda.

According to Hiatt (2006), ADKAR is an acronym for:

$A=$ Awareness of the need for change

$\mathrm{D}=$ Desire to support and participate in the change

$\mathrm{K}=$ Knowledge of how to change

$A=$ Ability to implement the change

$\mathrm{R}=$ Reinforcement to sustain the change

Therefore, the ADKAR Model stands for awareness of agents, their desire for change, their knowledge about change, ability to change and reinforcement to keep change happening. The ADKAR Model is capable of providing useful framework for Ministry of Education and Sports to effectively plan and execute effectively Higher education students' loan in HEIs in Uganda. Application of ADKAR Model is to help in determining the extent to which awareness, desire, knowledge, ability and reinforcement can lead to the success of higher education students` loan being implemented in Uganda.

This study might enable the different stakeholders involved in the management of student loan to identify its achievements, challenges and draw lessons to inform way forward for the implementation of the aforesaid policy. Besides, the study is expected to generate useful data to inform exact intervention for implementation of the aforesaid policy. This will therefore, directly contribute to improving the quality of student loan policy at institutions of Higher Learning in Uganda. The specific objectives of the study were to:

1. Establish the relationship between the ADKAR model and disbursement of student loans.

2. Explore the relationship between the ADKAR model and appreciation of the interest rate charged on student loans.

3. Ascertain the relationship between the ADKAR model and recovery of student loans.

\section{$2 \quad$ Related Literature}

The ADKAR Model was advanced by Jeff Hiatt in 1996 basing on analysis of research data from over 900 organizations over a 10 -year period. However, it was not until 1999 that it was first published in a white paper titled The Perfect Change. According to Hiatt (2006), there are five milestones an organization or an individual must achieve for change to be successful: awareness, desire, knowledge, ability and 
reinforcement. Hence, for one to effectively implement change there is need for awareness of the need for change; desire to participate and support the change; knowledge of how to change; ability to implement the change on a day-to-day basis; and reinforcement to keep the change in place. Hence, the ADKAR Model reflects the necessary building blocks for individual change and was developed. This model was deemed ideal for this study because it represents the five milestones an individual or organisation must achieve for change to be successful: awareness, desire, knowledge, ability and reinforcement.

Accordingly, awareness involves making those who going to experience the change mindful of what will be occurring, why, and how it is relevant to them. Awareness helps in making clear and compelling case for why the change is needed. Therefore, creation of awareness of change leads to an understanding of the nature of the change and why this change is needed. Awareness of change can be created by specifying the nature of the change and indicating how the change align with the vision for the organization; stating why change is made and the risks of not changing; specifying how change will impact a given organization or community; and stipulating the benefits of engaging in change initiative.

Desire consists of galvanizing change to welcome, want and embrace the change. It is the urge for change targets to buy into the new direction or to be part of change; while knowledge is necessary in change initiatives because it involves giving those experiencing change the information which enables them to endorse the change. For example, organizational change cannot happen without the stakeholders understanding clearly about the change proposed and also their role in the same.

The ability to adapt to change involves developing a capacity of people to deal with desired change; while reinforcement is a process of strengthening desirable behavioural change. It is aimed at making change stick and to realize the desired benefits of a change. Reinforcement is critical to the success of all initiatives because people have a natural tendency to revert back to what they know and are comfortable with. Reinforcement of change may entail the use of celebrations, rewards and recognition, feedback, corrective actions, visible performance measurement, and accountability mechanisms.

\section{$3 \quad$ Methodology}

\subsection{Design}

Cross-sectional survey and Correlational research designs guided the study. The use of a cross-sectional design made it possible to collect data at one point in time. It also ensured that only current information was collected. 


\subsection{Participants}

The study participants consisted of 400 students benefiting from the Higher Education Students Loan. These were selected from Bugema University, Busitema University, Kisubi University, Kyambogo University Makerere University, and Ndejje University. The six universities were selected because they have the majority of the student loan beneficiaries. Majority (78 percent) of the respondents were male. The respondents were drawn from study programmes in Agriculture, Architecture, Education, Engineering, Technology, Medicine, Environmental Science and Forestry - because students from these programs comprise majority of beneficiaries. Most of the students were in their third year followed by those who were in the first and second years.

\subsection{Data Collection and Instrumentation}

Questionnaires were used to collect data. In particular, a closed-ended questionnaire used enabled the researchers to raise fixed responses that enabled easy comparison of data obtained from different student loan beneficiaries from universities in Uganda. Questionnaires were deemed ideal for collecting data for this study because they made collection of data easy from a wide population of student loan beneficiaries from both private and public universities in Uganda within the shortest time. Specifically, closed-ended questionnaires led to fixed responses that enabled easy comparison of data obtained from different student loan borrowers from different universities in Uganda.

Appropriate measures were instituted to enhance the validity and reliability of the study findings. Generally, validity of the questionnaire was ensured by subjecting it to scrutiny and assessment for the relevancy of each item to the research objectives. Thereafter, necessary adjustments were effected and only relevant items were used for data collection. On the other hand, reliability of the questionnaire was established by pretested using 15 students from one of the universities hosting students benefiting from Higher Education students loan in Uganda. The pilot questionnaire enabled made it possible to establish the consistency in responses of informants. In addition, internal consistency reliability was established using Cronbach alpha. The internal consistency Cronbach coefficient of the questionnaire used was established at 0.89 .

\subsection{Analysis}

Data were analysed using both Pearson correlation and regression analysis. The use Pearson Correlation made it possible to establish whether a relationship exists between ADKAR and the management of the student loan. Subsequently, multiple (linear) regression analysis was used to particularize the relationships established. Furthermore, application of this technique made it possible to predict the aspects of ADKAR that are significantly related to the management of the student loan. 


\subsection{Limitations}

The information reported accrued from cross-sectional data, which makes it difficult to draw a valid picture of the management of the higher education students' loan over a long period of time. As well, it should be noted that data collection focused on the respondents' perceptions of the relationship between ADKAR and management of the higher education student loan.

\section{$4 \quad$ Findings}

The findings are summarized in Tables 2 through 13.

Table 2. Pearson Correlation Coefficient for ADKAR and Loan Management

\begin{tabular}{|c|c|c|c|}
\hline \multirow[t]{2}{*}{ ADKAR Model } & \multicolumn{3}{|c|}{ Loan Management } \\
\hline & Loan Disbursement & Loan Interest & Loan Recovery \\
\hline $\begin{array}{l}\text { Awareness of need to } \\
\text { change }\end{array}$ & $.460 * *$ & $.323 * *$ & $.546^{* *}$ \\
\hline Desire to change & $.260 * *$ & $.113^{*}$. & $.186^{* *}$ \\
\hline Knowledge to change & $.420 * *$ & $.200 * *$ & $.296^{* *}$ \\
\hline Ability to change & $.370 * *$ & $.255^{* *}$ & $.261 * *$ \\
\hline Reinforcement of change & $.228 * *$ & $.154 * *$ & $.172 * *$ \\
\hline
\end{tabular}

* Correlation is significant at the 0.05 level (2-tailed).

** Correlation is significant at the 0.01 level (2-tailed).

Table 2 indicates that relationship existed between the five elements of the ADKAR model and the three attributes of the student loan scheme investigated. The coefficients of this relationship suggest that "desire to change" accounted for $6.8 \%$ of the variance in disbursement. On "loan interest", the coefficient of determination was found to be 0.013 , implying that "desire to change" accounted for $1.3 \%$ of the variable. For recovery, this percentage was established at 3.5. The coefficients of determination of "knowledge to change" and loan disbursement, interest charged and recovery were respectively found to be 17.6 per cent, 4 per cent and 8.8 percent. The coefficient of determination of "ability to change" and loan disbursement, interest and recovery was respectively found to be 13.7, 6.5 and 6.8 per cent. On "reinforcement of change", the coefficients of determination were 8.3, 2.4 and 2.9 percent for disbursement, interest and recovery respectively. Regression Analysis was conducted to establish the elements of the ADKAR Model that predicted the management of the student loan scheme. 
Table 3. Relationship between ADKAR and Disbursement of Loans to Students

\begin{tabular}{lllll}
\hline Model & R & R Square & Adjusted R Square & Std. Error of the Estimate \\
\hline 1 & $.460 \mathrm{a}$ & .212 & .210 & 4.77992 \\
2 & $.508 \mathrm{~b}$ & .258 & .254 & 4.64510 \\
3 & $.519 \mathrm{c}$ & .270 & .264 & 4.61377 \\
\hline
\end{tabular}

a. Predictors: (Constant), awareness

b. Predictors: (Constant), awareness, knowledge

c. Predictors: (Constant), awareness, knowledge, ability

The results reported in Table 3 show a model Summary of regression analysis of relationship between ADKAR and Disbursement of Loans. The R-Squared model in Table 4 reveals that the regression analyses of the relationship between ADKAR and Disbursement of Loans yielded three (3) predictors for Disbursement of Loans. These predictors are awareness, knowledge, and ability to change. Specifically, the R-Squared model indicates that awareness (aspect of ADKAR) accounted for only 21.2 per cent; knowledge of change accounted for only 26 per cent; while ability to change accounted for only 27 per cent of the variance in loan disbursement. This implies that desire for, and reinforcement of change are not significant predictors of loans disbursed to students in universities in Uganda. Hence, providers of Higher Education Student Loan should concentrate on awareness creation, boosting knowledge of loan recipients and on empowering loan recipients to acquire ability to change in view of the changing patterns in financing of higher education in Uganda.

Table 4. ANOVA in Relationship between ADKAR and Disbursement of Loans

\begin{tabular}{lllllll}
\hline Model & Sum of Squares & Df & Mean Square & F & Sig. \\
\hline 1 & Regression & 2440.684 & 1 & 2440.684 & 106.824 & $.000^{\mathrm{a}}$ \\
& Residual & 9070.504 & 397 & 22.848 & & \\
& Total & 11511.188 & 398 & & & \\
2 & Regression & 2966.725 & 2 & 1483.363 & 68.748 & $.000^{\mathrm{b}}$ \\
& Residual & 8544.463 & 396 & 21.577 & & \\
& Total & 11511.188 & 398 & & & \\
3 & Regression & 3102.867 & 3 & 1034.289 & 48.588 & $.000^{\mathrm{c}}$ \\
& Residual & 8408.321 & 395 & 21.287 & & \\
& Total & 11511.188 & 398 & & & \\
\hline
\end{tabular}

a. Predictors: (Constant), awareness

b. Predictors: (Constant), awareness, knowledge

c. Predictors: (Constant), awareness, knowledge, ability

d. Dependent Variable: loan disbursement

Table 4 shows that awareness of change, knowledge of change, and ability to change are significant predictors of loan disbursement to students. This implies that there 
is significant positive relationship between some aspects of ADKAR and loans disbursement.

Table 5. Regression Coefficients of the Relationship between ADKAR and Disbursement of Loans offered

\section{Unstandardized Coefficients Standardized Coefficients}

\begin{tabular}{ccccccc}
\multicolumn{2}{c}{ Model } & B & Std. Error & Beta & t & Sig. \\
\hline 1 & (Constant) & 13.346 & 1.333 & & 10.010 & .000 \\
& awareness & .427 & .041 & .460 & 10.336 & .000 \\
2 & (Constant) & 12.174 & 1.317 & & 9.242 & .000 \\
& awareness & .302 & .047 & .326 & 6.375 & .000 \\
& knowledge & .266 & .054 & .253 & 4.938 & .000 \\
3 & (Constant) & 11.152 & 1.369 & & 8.143 & .000 \\
& awareness & .267 & .049 & .288 & 5.443 & .000 \\
& knowledge & .219 & .057 & .208 & 3.859 & .000 \\
& ability & .284 & .112 & .131 & 2.529 & .012 \\
\hline
\end{tabular}

a. Dependent Variable: Loan Disbursement

Table 5 shows that the regression coefficients and t-test measuring the relationship between ADKAR and Disbursement of student Loans led to positive numbers. This implies that awareness, knowledge, and ability to change had a positive relationship with student loan disbursement. To test whether ADKAR had a positive relationship with appreciation of the interest charged on loans, all the elements of ADKAR were correlated with it.

Table 6. Model Summary of Regression Analysis of Relationship between ADKAR and appreciation of Loan Interest Charged Loans

\begin{tabular}{lllll}
\hline Model & $\mathrm{R}$ & $\mathrm{R}$ Square & Adjusted R Square & Std. Error of the Estimate \\
\hline 1 & $.323^{\mathrm{a}}$ & .104 & .102 & 2.12462 \\
2 & $.347^{\mathrm{b}}$ & .121 & .116 & 2.10754 \\
\hline
\end{tabular}

a. Predictors: (Constant), awareness

b. Predictors: (Constant), awareness, ability

Table 6 shows that regression analysis of relationship between ADKAR and appreciation of the interest charged on loans yielded two predictors: awareness of need to change and ability to embrace change. The R-Squared model indicates that awareness of change accounted for only 10.4 per cent; while ability to change accounted for only 12.1 per cent in the variance in appreciation of the interest charged on loans. 
Table 7. ANOVA Summary of Regression Analysis of Relationship between ADKAR and appreciation of Loan Interest Charged

\begin{tabular}{llllll}
\hline Model & Sum of Squares & Df & Mean Square & F & Sig. \\
\hline 1 Regression & 208.310 & 1 & 208.310 & 46.148 & $.000^{\mathrm{a}}$ \\
Residual & 1792.056 & 397 & 4.514 & & \\
$\quad$ Total & 2000.366 & 398 & & & \\
2 Regression & 241.441 & 2 & 120.720 & 27.179 & $.000^{\mathrm{b}}$ \\
$\quad$ Residual & 1758.925 & 396 & 4.442 & & \\
$\quad$ Total & 2000.366 & 398 & & & \\
\hline
\end{tabular}

a. Predictors: (Constant), awareness

b. Predictors: (Constant), awareness, ability

c. Dependent Variable: loan interest

In Table 7, the ANOVA summary shows that awareness of and, ability to embrace change are significant predictors for appreciation of loan interest charged on students benefiting from higher education student loan in Uganda.

Table 8. Regression Coefficients of Relationship between ADKAR and appreciation of Interest Charged on Loans

\begin{tabular}{llccccc}
\hline & & \multicolumn{3}{c}{ Unstandardized Coefficients } & \multicolumn{3}{c}{ Standardized Coefficients } & & \multirow{2}{*}{ Sig. } \\
\multicolumn{1}{l}{ Model } & $\mathrm{B}$ & Std. Error & Beta & & \\
\hline 1 & (Constant) & 5.217 & .593 & & 8.804 & .000 \\
& awareness & .125 & .018 & .323 & 6.793 & .000 \\
2 & (Constant) & 4.644 & .624 & & 7.440 & .000 \\
& awareness & .098 & .021 & .254 & 4.747 & .000 \\
& ability & .132 & .048 & .146 & 2.731 & .007 \\
\hline
\end{tabular}

a. Dependent Variable: loan interest

Table 8 shows that the regression Coefficients and t-test measuring the relationship between ADKAR and appreciation of interest on student loan led to positive numbers. This implies that only two (2) items of ADKAR (awareness, and ability to change) had a positive relationship with appreciation of interest. This implies that desire for, knowledge and reinforcement of change are not significant predictors of appreciation of interest. Regression analysis was conducted to test whether there was significant positive relationship between ADKAR and recovery.

Table 9. Model Summary of Regression Analysis of Relationship between ADKAR and Loan recovery

\begin{tabular}{lllll}
\hline Model & R & R Square & Adjusted R Square & Std. Error of the Estimate \\
\hline 1 & $.546^{\mathrm{a}}$ & .298 & .296 & 2.55582 \\
\hline
\end{tabular}

a. Predictors: (Constant), awareness 
Table 9 shows a model Summary of Regression Analysis of relationship between ADKAR and recovery on Loans offered to Higher Education Students in Uganda revealing one predictor (awareness of change) for loan recovery. The R-Squared model indicates that awareness of change accounted for about 30 per cent in the variance in loan recovery.

Table 10. ANOVA of Regression of Relationship between ADKAR and recovery on Loans offered to Higher Education Students in Uganda.

\begin{tabular}{|c|c|c|c|c|c|}
\hline Model & Sum of Squares & Df & Mean Square & $\mathrm{F}$ & Sig. \\
\hline 1 Regression & 1099.689 & 1 & 1099.689 & 168.349 & $.000^{\mathrm{a}}$ \\
\hline Residual & 2593.289 & 397 & 6.532 & & \\
\hline Total & 3692.977 & 398 & & & \\
\hline
\end{tabular}

a. Predictors: (Constant), awareness

b. Dependent Variable: Loan Recovery

The ANOVA results in Table 10 show that awareness of need to change is a significant predictor of loan recovery. This implies that to ensure effective recovery of the loans that they disburse, the implementers of the loan scheme should concern themselves more with awareness creation than with anything else.

Table 11. Regression Coefficients of relationship between ADKAR and recovery on Loans offered to Higher Education Students in Uganda.

\begin{tabular}{cccccc}
\hline Model & \multicolumn{2}{c}{ Unstandardized Coefficients } & \multicolumn{3}{c}{ Standardized Coefficients } \\
& $\mathrm{B}$ & Std. Error & Beta & $\mathrm{t}$ & Sig. \\
\hline 1 (Constant) & 4.908 & .713 & & 6.884 & .000 \\
awareness & .286 & .022 & .546 & 12.975 & .000 \\
\hline
\end{tabular}

a. Dependent Variable: loan recovery

Table 11 shows that the regression coefficients and t-test measuring the relationship between ADKAR and recovery on student Loans led to positive numbers. Table 10 further shows that only one item of ADKAR (i.e. awareness of change) had a positive relationship with student loan recovery.

\section{Discussion}

There is significant relationship between ADKAR and Disbursement of Loan. The results revealed that awareness, knowledge, and ability to change are the three (3) predictors of Loan Disbursement. This implies that student loan beneficiaries should be made empowered, aware and knowledgeable about Higher Education 
Student Loan scheme for students in Uganda. This can be done by training loan beneficiaries on regular basis on how to put to better use the acquired loan facility.

Upon approval of student loan, HESFB must notify the loan beneficiary in writing of the student loan approved and disbursed. The notice should include the amount of the loans and when and how the student borrower should expect to receive it. The current practice of informing students through universities is not adequate in creating awareness of what is expected of the student loan borrowers. Student loan borrowers should be made aware of the implications/possibility to cancel a student loan after disbursement. First of all, students need reliably accessible, timely, accurate, and comparable information about student loan in order to make informed decisions about whether to take on student loan or not. The rise in the numbers of default could be avoided if loan servicers provided better assistance and information to financially challenged student loan borrowers. It is important to have clear payment instructions and expectations at the point of loan disbursement. Creation of awareness will enable the student loan borrowers to get to know details on the loan they intend to secure. This can help them to avoid defaulting by making sure that all payments are going to the right place as directed by the HESFB. This implies that HESFB (loan providers) should be able to supply student loan borrowers with all pertinent information related to Higher Education Students loan, including information on the balance due, required monthly payment, interest rate and payoff date. This implies that HESFB should provide student loan borrowers with key information on the loan secured. The information on the loan secured should be reliably accessible, timely, and accurate. Prior to disbursement, universities should educate and train the student loan borrowers and guarantors about the implications of obtaining a loan, how the loan works, the benefits of paying on time and complying with payment schedule. For this to happen, it is it is necessary for HESFB to have in place an efficient information system to facilitate the monitoring of past-due student borrowers.

There is significant relationship between ADKAR and appreciation of repayment rate yielded two (2) predictors for appreciation of repayment rate charged on students benefiting from Higher Education Student Loan in Uganda. Specifically, the results revealed that awareness of and, ability to embrace change are the two (2) predictors of Loan Interest Charged on students.

This implies that high repayment rates can result into a high repayment burden on student borrowers with low income. Therefore, setting preferential (affordable) repayment rates is one of the ways of securing payment commitment from student loan borrowers.

This implies that the Board overseeing Higher Education Student Loan should actively engage in on awareness creation in a bid to make loan beneficiaries appreciate of the repayment rate charged on student loan. This further implies that the overseers of Higher Education Student Loan should enable students benefiting Higher Education Student Loan to easily find information on how to access Loan; and to perform to the expectations of Higher Education Student Loan; as well as 
empower student loan beneficiaries to put knowledge of student Loan scheme requirements into practice to make loan beneficiaries appreciate of the interest rate charged on student loan. This can further be improved by making interest rates affordable, insulted against protect the exploitation of beneficiaries, taking into consideration inflation realities that mat occur over the period of the loan.

There is significant relationship between ADKAR and recovery on Loans offered to Higher Education Students in Uganda. The results revealed that awareness of change was only predictor for Loan recovery from students benefiting from Higher Education Student Loan in Uganda. This implies that the Board overseeing Higher Education Student Loan should concentrate on awareness creation the urgency of paying back the loan so that loan recovery activities can go on smoothly. This can be done by having open mechanism of making possible candidates aware of the existing loan opportunities, spelling out what is expected of loan beneficiaries; and making them aware of their obligation to pay back the student loan offered to them; as well as making them aware of the legal consequences if they default on paying back the loan offered to them as it has been the case elsewhere (Monteverde,2000; Podgursky, Ehlert, Monroe, Watson, \&Wittstruck,2002).It also important to make beneficiaries aware of repayment periods for student loan offered to them using appropriate media and agents. Importantly, the Board overseeing Higher Education Student Loan should properly assess the borrower`s ability to pay back the loan amount received from Higher Education Student Loan after completion of studies.

There is need to design a variety of strategies to recover loans disbursed to students in HEIs. This involves, among others, developing some strong collection strategies with clearly defined, documented and consistent policies and procedures that guide staff through the loan recovery process.

To make recovery of student loan more effective, there should be regular updating of bank debt recovery system. Loan recovery requires set of coordinated, appropriate, and timely activities aimed at full collection of loans from clients. Loan recovery necessitates interaction with the client, beginning with a careful analysis of the client's situation and frequent contact over the duration of the loan. In addition, student borrowers deserve to be offered payment alternatives that are timely and appropriate to each situation, and all loan recovery activities should be documented to facilitate continuous follow-up activities.

The HESFB must help student loan borrowers to develop desire to repay the loan. Involving student loan borrowers in the establishment of mutually agreeable payment dates may increase the likelihood of repayment. The use of positive reinforcement positive reinforcement is likely to play a valuable role. It would be helpful for HESFB to reward student loan borrowers who pay on time. This could be done by offering prizes, certificates of good payment, and training to borrowers who pay on time. There is also need for credit counselling to foster education to borrower on how to manage the debts burden and repayment commitments. 


\section{Conclusion}

Awareness, desire, knowledge, and ability to change must considered before loan disbursement, determination of repayment rates and loan recovery. Adoption of ADKAR Model in the management of Higher Education Student Loan is likely to lead to minimization of Loan defaulting and boost efficiency of Higher Education Students Financing Loan Board (HESFLB). The use of ADKAR Model will enable HESFLB to establish the borrowers' financial capacity, in terms of disposable income available for orderly debt repayment, and willingness to repay; as well as allowing for provision of additional information on how support can be sought if student loan borrowers are unable to make loan payments after program completion or graduation.

\section{References}

Avery, C. \& Turner, S. (2012). Student loans: do College students borrow too much - or not enough? Journal of Economic Perspectives, 26(1), 165-192.

Dynarski, M. (1994). Who defaults on student loans? Findings from the National Postsecondary Student Aid Study. Economics of Education Review, 13(1), 55-68.

Greene, L. L. (1989). An economic analysis of student loan default. Educational Evaluation and Policy Analysis, 11(1), 61.

Herr, E., \& Burt, L. (2005). Predicting student loan default for the University of Texas at Austin. Journal of Student Financial Aid, 35(2), 27-49.

Hiatt, J. (2006). ADKAR-A model for change in Business, Government and our Community. Loveland CO: Prosci Research.

Kampala: Ministry of Education \&Sports.

Monteverde, K. (2000). Managing student loan default risk: evidence from a privately guaranteed portfolio. Research in Higher Education, 41(3), 331-352.

Podgursky, M., Ehlert, M., Monroe, R., Watson, D., \& Wittstruck, J. (2002). Student loan defaults and enrollment persistence. Journal of Student Financial Aid, 32(3), 27-42.

Shakeela, F. (2010). Viability of a student loan scheme in the Maldives. Master of Philosophy in Higher Education Thesis Submitted to Faculty of Education, Universiteteti, Oslo.

Uganda Government (2012). The Uganda Students' Higher Education Financing Policy. Uganda Government (2014). Higher Education Students Financing Board Act of 2014.Entebbe: UPPC.

Uganda Government (2019). Ministerial Press Release on Hints and Facts on Higher Education Students' Financing Policy, Kampala: Ministry of Education \& Sports.

Woodhall, M. (1991). Student loans in higher education. Paris: International Institute of Educational Planning. 